\title{
PELATIHAN MANAJEMEN KEUANGAN DAN TATA LETAK PENGOLAHAN BAKSO CITAMIANG PADA UMKM BAKSO DI KECAMATAN CIBEUNYING KIDUL KOTA BANDUNG
}

\author{
Resi Juariah \\ resi.juariah@gmail.com \\ Anton Mulyono Azis \\ anton.mulyono@ekuitas.ac.id \\ Fia Dialysa \\ fdialysa@gmail.com
}

SEKOLAH TINGGI ILMU EKONOMI EKUITAS

\begin{abstract}
ABSTRAK
Progam pengabdian masyarakat yang dilakukan bertujuan untuk memberikan pelatihan sebagai salah satu upaya meningkatkan keterampilan untuk pengusaha bakso di lingkungan Kecamatan Cibeunying Kidul Kota Bandung berupa pelatihan manajemen keuangan dan tata letak. Masalah yang sering dihadapi oleh para pengusaha bakso diantaranya adalah kurang dalam mengatur tata letak dan mengatur keuangan usaha. Hal ini disebabkan minimnya pengetahuan pengusaha bakso mengenai cara bagaimana pengaturan tata letak dan manajemen keuangan yang baik dalam suatu proses produksi sebagai sarana pembantu dalam melakukan usaha oleh para pengusaha bakso di lingkungan Kecamatan Cibeunying Kidul Kota Bandung. Permasalahan yang terjadi saat ini adalah bahwa pelaku usaha masih sangat sederhana dan ala kadarnya dalam melakukan pengaturan tata letak dan manajemen keuangan yang ada dimana dapat memakan waktu dan biaya karena kurangnya pengaturan tersebut. Mitra Program Pengabdian Masyarakat ini adalah pengusaha bakso di lingkungan Kecamatan Cibeunying Kidul Kota Bandung. Solusi yang diberikan berupa Pelatihan Manajemen Keuangan dan Tata Letak pengolahan bakso di lingkungan Kecamatan Cibeunying Kidul Kota Bandung. Hasil dari pengabdian pada masyarakat ini, yaitu peningkatan profit usaha dan keberlangsungan bisnis bakso agar dapat berdaya saing tinggi dan para UMKM khususnya di Kecamatan Cibeunying Kidul dan juga mitra menjadi lebih termotivasi untuk menjadi entrepreneur sejati.
\end{abstract}

Kata kunci: Manajemen Keuangan, Manajemen Tata Letak, Pengolahan Bakso..

\section{PENDAHULUAN}

Kecamatan Cibeunying Kidul merupakan salah satu bagian wilayah administratif Kota Bandung dengan memiliki luas lahan sebesar 512,34 Ha. Koordinat 107 38'14,272" E (BT) 6 $58 ' 59,365 "$ S (LS). Secara geografis
Kecamatan Cibeunying Kidul memiliki bentuk wilayah datar/ berombak sebesar 90\% dari total keseluruhan luas wilayah. Ditinjau dari sudut ketinggian tanah, Kecamatan Cibeunying Kidul berada pada ketinggian 500 meter diatas permukaan air laut. Suhu maksimum dan minimum di 
Kecamatan Cibeunying Kidul berkisar $32^{\circ} \mathrm{C}$ dan $19^{\circ} \mathrm{C}$, sedangkan dilihat dari segi hujan berkisar $874 \mathrm{~mm} /$ th dan jumlah hari dengan curah hujan yang terbanyak sebesar 45 hari. Secara administratif Kecamatan Cibeunying Kidul dibatasi oleh:

- Bagian Selatan : Kecamatan Kiaracondong dan Batununggal

- Bagian Utara : Kecamatan Cimenyan - Kabupaten Bandung

- Bagian Timur : Kecamatan Antapani

- Bagian Barat : Kecamatan Cibeunying Kaler, Sumur Bandung dan Bandung Wetan

Kota Bandung (kotamadya) adalah ibu kota propinsi Jawa Barat. Kota ini pada zaman dahulu dikenal sebagai Parijs van Java (bahasa Belanda) atau "Paris dari Jawa“. Karena terletak di dataran tinggi, Bandung dikenal sebagai tempat yang berhawa sejuk. Hal ini menjadikan Bandung sebagai salah satu kota tujuan wisata. Sedangkan keberadaan perguruan tinggi negeri dan banyak perguruan tinggi swasta di Bandung membuat kota ini dikenal sebagai salah satu kota pelajar di Indonesia.

Sejak didirikan tahun 1801, Bandung yang asalnya hanyalah sebuah Desa, mengalami perkembangan dan perluasan wilayah. Dan pada tahun 1921 Wilayah Cibeunying sudah termasuk ke dalam Kotamadya Bandung. Sejak saat itu berkembanglah wilayah Cibeunying dengan segala potensi unggulannya, terutama kuliner dan kesenian sampai dengan sekarang.

Cibeunying berasal dari kara "Ci" dan "Beunying". Ci berasal dari kata "Cai" dalam Bahasa sunda, yang berarti Air. Di Kota Bandung banyak daerah yang diawali kata $\mathrm{Ci} / \mathrm{Cai}$ karena banyak sungai dan anak sungai yang menjadi pusat kehidupan di Kota Bandung pada zaman dahulu. Sedangkan kata "Beunying" diambil dari nama tanaman lokal (Ficus fistulosa Reinw. ex Blume) merupakan jenis tumbuhan dari familyMoraceae atau keluarga beringin.
Masih satu kerabat dengan nangka, murbei, pohon bodhi, karet munding, dan hampelas.Beunying adalah pohon dengan tinggi yang dapat mencapai $10 \mathrm{~m}$. Daunnya tebal dan berbentuk bulat telur sampai lonjong hingga lanset. Permukaan bagian atas mengkilat bertangkai panjang. Karangan bunga periuk, tumbuh dari ketiak daun atau bergerombol pada batang.Beunying hidup di tempat sejuk dan dekat sumber air dengan elevasi hingga $2.000 \mathrm{~m}$. Di hutan terbuka, pinggiran hutan yang lembap banyak ditumbuhi oleh jenis ini. Namun sayangnya saat ini jarang sekali ditemukan pohon Beunying di Kota Bandung.Setelah pemekaran, Cibeunying dibagi 2 menjadi Kecamatan Cibeunying Kidul dan Cibeunying kaler berdasarkan letaknya yang bersisian di sebelah kidul (selatan) dan kaler (utara). (Sumber: Wikipedia.org)

Pada tahun 1987 dikeluarkan Peraturan Pemerintah Republik Indonesia Nomor 16 Tahun 1987 mengenai Perubahan Batas Wilayah Kotamadya Daerah Tingkat II Bandung dan Kabupaten Bandung, yang diantaranya memuat pemekaran wilayah kecamatan sebagai berikut:

1. Sebagian wilayah Kecamatan Cicadas Kabupaten Bandung, yaitu Kelurahan Padasuka

2. Pemekaran 16 Kecamatan menjadi 26 Kecamatan.

3. Pemekaran Kecamatan Cibeunying Menjadi 2; Kecamatan Cibeunying Kidul dan Kecamatan Cibeunying Kaler.

4. Pusat pemerintahan Kecamatan Cibeunying Kidul berada di Kelurahan Cikutra (Jl. Sukasenang)

5. Kelurahan yang masuk kedalam kecamatan Cibeunying Kidul adalah:

- Sebagian Desa Padasuka

- Kelurahan Cikutra

- Kelurahan Cicadas

- Kelurahan Sukamaju

- Kelurahan Pasirlayung

- Kelurahan Sukapada 
Selanjutnya, dikeluarkan Perda Kota Bandung No. 06 Tahun 2006 tentang Pemekaran dan Pembentukan Wilayah Kerja Kecamatan dan kelurahan di Lingkungan Pemerintah Kota Bandung, Kecamatan Cibeunying Kidul membawahi 6 (enam) Kelurahan yaitu:

- Kelurahan Padasuka

- Kelurahan Cikutra

- Kelurahan Cicadas

- Kelurahan Sukamaju

- Kelurahan Pasirlayung

- Kelurahan Sukapada

Pada tahun 2006, Kecamatan Cibeunying Kidul masuk ke dalam rencana pengembangan Wilayah Cibeunying yang menjadi sentra Ekonomi Kreatif dengan produk unggulan Kaos/Sablon.Pada tahun 2011, dalam Rencana Tata Ruang WilayahKota Bandung, yang terdiri dari 2 (dua) pusat wilayah pelayanan 8 (delapan) Sub-Pusat wilayah pelayanan. Kecamatan cibeunying masuk kedalam struktur pusat pelayanan I (Alun-alun) dan termasuk dalam Sub-Pusat Pelayanan Sadang Serang.

Di wilayah Kecamatan Cibeunying Kidul Kota Bandung, terdapat pengusaha pengolahan bakso yang menjadi mitra pengabdian kepada masyarakat saat ini berjumlah 13 (tiga belas) industri pengolahan bakso. Lokasi dari satu industri ke industri lainnya saling berdekatan di daerah Kecamatan Cibeunying Kidul. Para pengusaha bakso tersebut, mayoritas memiliki kios di wilayahnya masingmasing. Mayoritas para pengusaha bakso memulai usahanya pada awal tahun 90-an, dan usaha tersebut sampai saat ini berkembang pesat. Hal ini disebabkan oleh minat masyarakat terhadap culinary di kota Bandung sangatlah tinggi terutama bakso. Konsumen dari berbagai daerah apabila mengunjungi kota Bandung belum afdol apabila belum mencicipi bakso khas kota Bandung. Salah satu bakso yang wajib dikunjungi adalah bakso Citamiang milik Bapak H. Harry. Beliau sudah menjalankan bisnis ini sejak tahun 1981, artinya sudah 37 tahun yang lalu. Bisnis yang dijalankan oleh Bapak H. Harry sudah mengalami berbagai kondisi pasang surut bisnis bakso. Kondisi terburuk dalam menjalankan usahanya yaitu pada tahun 1996 pada saat krisis ekonomi yang terjadi di Indonesia secara serentak, namun hal ini tidak berlangsung lama, sehingga setahun berikutnya usaha beliau sudah mulai stabil kembali.

Prinsip Bapak H. Harry dalam menjalankan bisnisnya yaitu selalu mengedepankan kualitas yang baik seperti dalam aspek produksi yang dalam pemilihan bahan bakunya hingga proses serta output yang dihasilkan mendapatkan kualitas yang terbaik.

Adapun aspek produksi yang terdapat pada pengusaha pengolahan bakso ini, meliputi:

1. Menentukan produk yang akan dihasilkan/dipasarkan, berdasarkan kebutuhan yang ada, yaitu produksi bakso yang sesuai dengan keinginan konsumen, karena dari setiap wilayah/target pasarnya, selera konsumen terhadap bakso sangat berbeda, seperti pada konsumen bakso yang akan membeli di wilayah pasar Kosambi memiliki selera ukuran bakso tidak harus berukuran besar, namun rasa bakso itu sendiri yang menjadi prioritas. Sebaliknya, untuk bakso Citamiang, kualitas selalu menjadi nomor satu dan tidak mementingkan masalah ukuran dan harga.

2. Menentukan jumlah produk. Dalam menentukan jumlah produk, para pengusaha bakso hanyalah memproduksi bakso sesuai dengan pesanan pembeli saja. Hal ini dilakukan agar tidak terjadi penumpukan inventory yang menyebabkan kerugian.

3. Menentukan kualitas produk. Dalam menentukan kualitas produk, para pengusaha bakso berusaha untuk dapat mengikuti permintaan konsumen, dengan cara melakukan perbandingan produk yang memiliki kualitas tertinggi dari setiap daerah di wilayah kota Bandung. 
Sumber daya yang ada saat ini pada para pengusaha bakso di daerah Kecamatan Cibeunying Kidul kota Bandung berasal dari hubungan kekerabatan pemilik usaha bakso tersebut. Hal ini dilakukan, karena untuk meminimalisir tingkat pengangguran dan menaikkan tingkat kepercayaan antara pemilik dan karyawan.

Hasil survey yang dilakukan sebelumnya menunjukkan bahwa masalah yang dihadapi oleh para pengusaha bakso di Kecamatan Cibeunying Kidul kota Bandung adalah masih bersatunya tempat usaha dengan tempat tinggal. Selain itu, pengelolaam manajemen keuangan pribadi dengan keuangan usaha yang juga tidak dikelola dengan baik. Para pengusaha bakso berpikir bahwa dalam proses produksi baksonya, tidak masalah apabila dilakukan di halaman rumah mereka, dan mereka juga berpikir bahwa keuangan tidak perlu dipisahkan antara keuangan pribadi dan keuangan usaha, karena yang menjadi prioritas utama adalah tercukupinya kebutuhan sehari-hari dan biaya operasional usaha. Berdasarkan hasil survei, untuk masalah tata letak pengolahan bakso yang selama ini dilakukan di area tempat tinggal, tidak sesuai dengan standar kelayakan manajemen operasional. Strategi tata letak merupakan salah satu keputusan kunci yang menentukan efisiensi operasi secara jangka panjang. Tata letak mempunyai sejumlah implikasi strategis karena hal tersebut dapat menyusun prioritas persaingan perusahaan yang berkaitan dengan kapasitas, proses, fleksibilitas dan biaya seperti kualitaskehidupan kerja, kontrak pelanggan danImage.Tata letak yang efektif dapatmembantu organisasi mencapai sebuah strategi yang menunjang low cost atau respons yang cepat. Tata letak terdapat pada semua bidang karena setiap fasilitas mempunyai tata letak. Setiap proses dalam fasilitas mempunyai tata letak yang harus direncanakan secara teliti.Tujuan strategi tata letak adalah untuk mengembangkan suatu sistem produksi yang efisien dan efektif sehingga dapat tercapainya suatu proses produksi dengan biaya yang paling ekonomis.(Heizer dan Render, 2015:532)

Selain permasalahan tata letak, para pengusaha pengolahan bakso ini, tidak melakukan pemisahan keuangan yang berasal dari usaha dan milik pribadi, yang mengakibatkan tidak terlihatnya profit/laba usaha secara konkrit, bersatunya asset/inventaris milik pribadi dan usaha yang apabila terjadi kerugian usaha, asset/inventaris tersebut akan turut tersit /terjual untuk menutupi kerugian tersebut. Manajemen keuangan merupakan aktivitas dalam hal mendapatkan dana perusahaan, mengorganisasikan dana tersebut dan memberikannya kepada investor secara tepat. Fungsi utamanya adalah (1) kegiatan mencari dana (obtain of fund) yang ditujukan untuk keputusan investasi yang menghasilkan laba, (2) kegiatan menggunakan dana (allocation of fund); dan (3) kegiatan mendistribusikan laba sebagai hasil kegiatan operasi.

Berdasarkan adanya fenomena tersebut, maka program pengabdian masyarakat yang akan dilakukan diharapkan mampu meningkatkan keefektifan dan pengoptimalan aplikasi manajemen keuangan dan tata letak dalam pengolahan bakso di Kecamatan Cibeunying Kidul kota Bandung.

Pelaksanaan pengabdian ini mempunyai target dan luaran:

1. Pelatihan dan Manual book atau modul untuk melakukan pelatihan manajemen keuangan dan tata letak yang mudah diaplikasikan para pengusaha bakso sehingga usaha dikemudian hari semakin terorganisir dengan baik.

2. Pelatihan dilaksakan dengan metode langsung terjun ke lapangan dengan melihat kondisi sekitar dan memberikan contoh langsung kepada para pelaku usaha tersebut.

\section{METODE KEGIATAN}

Metode pelaksanaan dalam pengabdian ini adalah: 
1. Tahapan Metode Pendekatan Masalah

Metode pendekatan yang ditawarkan untuk menyelesaikan persoalan mitra adalah dengan melakukan diskusi antara tim STIE Ekuitas dengan para pengusaha bakso untuk lebih mengetahui kendala dan hambatan dalam menjalankan usaha. Hasilnya yaitu Pemahaman persamaan persepsi dari pihak yang terkait, dalam hal ini tim STIE Ekuitas dengan pengusaha bakso di wilayah Kecamatan Cibeunying Kidul kota Bandung.

\section{Tahapan Prosedur Kerja}

Pelatihan manajemen keuangan dan tata letak sebagai cara untuk mengatasi persoalan yang telah dibahas sebelumnya. Hasilnya yaitu modul pelatihan manajemen keuangan dan tata letak.

3. Tahapan Rencana Kegiatan

Pelatihan manajemen keuangan dan tata letak dengan menggunakan modul dan terjun langsung ke lapangan. Hasilnya yaitu modul pelatihan dan mendampingi para pelaku dalam lapangan ketika dilakukan simulasi atau pemberian contoh.

Adapun metode pelatihan yang dilakukan akan bersifat:

- Teaching. Metode ini merupakan metode transfer knowledge dimana penyampaian materi akan dilakukan satu arah dari fasilitator kepada para peserta.

- Teach to Learn. Pada metode ini, peserta akan diberikan waktu untuk menerangkan apa yang telah diperoleh selama pelatihan kepada peserta lainnya. Hal ini dilakukan dengan keyakinan bahwa peserta telah mengerti apa yang disampaikan fasilitator ketika dapat menerangkannya kepada orang lain.
- Praktek (latihan). Para peserta akan berlatih melalui pengaplikasian teori yang diperoleh.

Adapun Luaran yang akan dihasilkan sesuai dengan rencana kegiatan baik dalam aspek produksi maupun manajemen usaha, yaitu berupa jurnal, dan modul untuk pengusaha pengolahan bakso.

\section{HASIL DAN LUARAN}

A. Hasil Kegiatan

Kegiatan pengabdian pada masyarakat yang dilakukan kepada para pengusaha bakso Kecamatan Cibeunying Kidul berlangsung pada tanggal 30 Mei 2018. Lokasi bertempat di salah satu tempat usaha bakso yaitu bakso Citamiang Bandung, yang dimulai pada pukul 07.00-12.00 WIB. Kegiatan diawali dengan pengenalan pentingnya manajemen keuangan sederhana dan manajemen tata letak proses pembuatan bakso. Selanjutnya yaitu sesi kunjungan langsung ke tempat produksi bakso sekaligus menjelaskan layout yang tepat agar proses produksi dapat berjalan secara lebih efektif dan efisien, serta manfaat dari layout yang baik agar proses produksi tepat sasaran, tepat guna dan tepat waktu.

Tahapan berikutnya yaitu pelatihan pembukuan sederhana bagi para pengusaha bakso yang bertujuan untuk meningkatkan keterampilan dan pengetahuan para pengusaha bakso, dapat memisahkan keuangan pribadi dengan usaha, serta para pengusaha dapat mengetahui perkembangannya melalui pembukuan yang baik. Dalam pelatihan pembukuan keuangan sederhana, yaitu meliputi : (Maulani, Dialysa, Prawirasasra; 2016:35) :

- Materi pembukuan keuangan sederhana secara umum. Dalam penyampaiannya menjelaskan bahwa pentingnya pembukuan keuangan dalam usaha kecil dan mikro, perlunya memisahkan keuangan pribadi dengan usaha agar pelaku usaha mudah menganalisis hasil usaha. 
- Laporan arus kas yang berfungsi menjelaskan tentang jumlah penerimaan dan pengeluaran kas perusahaan dalam satu periode beserta sumber-sumbernya.

- Laporan laba rugi yang berfungsi memberikan informasi tentang aktifitas bisnis perusahaan misalnya Penjualan, Beban, dan Laba atau Rugi Bersih.

- Laporan perubahan modal yang berfungsi menggambarkan peningkatan atau penurunan aktiva bersih atau kekayaan selama periode yang bersangkutan berdasarkan prinsip pengukuran tertentu yang dianut.

- Neraca yang berfungsi menjelaskan nilai Aset, Kewajiban dan Modal perusahaan pada suatu tenggal tertentu.

- Penerapan materi pada soal-soal kasus usaha.

Peningkatan produktivitas merupakan salah satu isu utama dalam pembahasan mengenai UKM khususnya di Indonesia. Banyak UKM yang belum mampu meningkatkan produktivitasnya sehingga masih sulit untuk berkembang dan bersaing dengan usaha skala besar. Produktivitas tidak hanya dimaknai dengan hasil akhir produksi ataupun tingkat penjualan yang tinggi saja, melainkan kemampuan UKM untuk melakukan efisiensi dan efektivitas produksi salam mencapai target penjualan. (Irjayanti, Azis, Juariah, 2016).

Kegiatan pelatihan ini tidak hanya satu arah, tetapi terjadi dua arah dengan adanya sesi diskusi. Diskusi berlangsung setelah penyampaian materi dengan tertib dan terarah Pada saat diskusi peserta berperan aktif melakukan tanya jawab, terkait dengan permasalahan yang dihadapi oleh pengusaha masing-masing.

\section{B. Indikator Keberhasilan}

Indikator keberhasilan dari program pengabdian pada masyarakat ini yaitu pemahaman tentang manajemen keuangan sederhana yang baik, serta lay out usaha dari para pengusaha bakso yang semakin baik dalam mengelola usahanya.

\section{KESIMPULAN}

Kesimpulan dari pengabdian ini adalah masih sangat dibutuhkannya manajemen keuangan sederhana yang baik dan pengaturan layout bagi para pengusaha bakso dalam mengelola usahanya. Hal ini bermanfaat bagi peningkatan profit usaha dan keberlangsungan bisnis bakso agar dapat berdaya saing tinggi dan para UMKM khususnya di Kecamatan Cibeunying Kidul dengan diadakannya pelatihan manajemen keuangan sederhana dan layout ini dapat lebih termotivasi untuk menjadi entrepreneur sejati.

\section{DAFTAR PUSTAKA}

Brigham, E.F., dan Joel, F.H. (2012). Dasardasar Manajemen Keuangan. Buku 1, Jakarta: Salemba Empat.

Heizer, J., Render, B. (2015). Manajemen Operasi. Buku 1 edisi 9. Jakarta: Salemba Empat.

Ikatan Akuntan Indonesia. (2012). Standar Akuntansi Keuangan. Jakarta: IAI

Irjayanti, M., Azis, A. M., dan Susanto, R. J. (2016). Penerapan Teknologi untuk Meningkatkan Produktivitas Usaha Kecil Menengah (Preliminary Study pada Industri Kreatif Usaha Kecil dan Menengah di Jawa Barat). Banking and Management Review. Vol. 5 No 1. Maulani, T. S., Dialysa, F., Prawirasasra, K. P. (2016). Pelatihan Pembukuan Keuangan Sederhana dan Motivasi Kewirausahaan pada Kelompok Usaha Makanan RW 02 Kelurahan Neglasari Kecamatan Cibeunying Kaler Bandung. Jurnal Dharma Bhakti Ekuitas Vol. 01 No. 01. 